\title{
A 250-year periodicity in Southern Hemisphere westerly winds over the last 2600 years
}

\author{
C. S. M. Turney ${ }^{1,2}$, R. T. Jones ${ }^{3}$, C. Fogwill ${ }^{1,2}$, J. Hatton ${ }^{3}$, A. N. Williams ${ }^{1,4}$, A. Hogg ${ }^{5}$, Z. A. Thomas ${ }^{1,2}$, J. Palmer ${ }^{1,2}$, \\ S. Mooney ${ }^{1}$, and R. W. Reimer ${ }^{6}$ \\ ${ }^{1}$ School of Biological, Earth and Environmental Sciences, University of New South Wales, Sydney, Australia \\ ${ }^{2}$ Climate Change Research Centre, School of Biological, Earth and Environmental Sciences, University of New South Wales, \\ Sydney, Australia \\ ${ }^{3}$ Department of Geography, Exeter University, Exeter EX4 4RJ, UK \\ ${ }^{4}$ Archaeological \& Heritage Management Solutions Pty Ltd, 2/729 Elizabeth Street, Waterloo, NSW 2017, Australia \\ ${ }^{5}$ Waikato Radiocarbon Laboratory, University of Waikato, Private Bag 3105, Hamilton, New Zealand \\ ${ }^{6}$ School of Geography, Archaeology and Palaeoecology, Queen's University Belfast, Belfast BT7 1NN, UK
}

Correspondence to: C. S. M. Turney (c.turney@unsw.edu.au)

Received: 24 April 2015 - Published in Clim. Past Discuss.: 3 June 2015

Revised: 13 January 2016 - Accepted: 17 January 2016 - Published: 3 February 2016

\begin{abstract}
Southern Hemisphere westerly airflow has a significant influence on the ocean-atmosphere system of the mid- to high latitudes with potentially global climate implications. Unfortunately, historic observations only extend back to the late 19th century, limiting our understanding of multi-decadal to centennial change. Here we present a highly resolved (30-year) record of past westerly wind strength from a Falkland Islands peat sequence spanning the last 2600 years. Situated within the core latitude of Southern Hemisphere westerly airflow (the so-called furious fifties), we identify highly variable changes in exotic pollen and charcoal derived from South America which can be used to inform on past westerly air strength. We find a period of high charcoal content between 2000 and 1000 cal. years BP, associated with increased burning in Patagonia, most probably as a result of higher temperatures and stronger westerly airflow. Spectral analysis of the charcoal record identifies a pervasive ca. 250year periodicity that is coherent with radiocarbon production rates, suggesting that solar variability has a modulating influence on Southern Hemisphere westerly airflow. Our results have important implications for understanding global climate change through the late Holocene.
\end{abstract}

\section{Introduction}

A major limitation for quantifying the magnitude and impact of change across the Southern Ocean is the relatively short duration or low resolution of ocean-atmosphere records. This is particularly significant with regards to the Southern Hemisphere westerly storm belt, which since the mid1970s, has undergone a significant intensification and southward shift (Gillett et al., 2008; Messié and Chavez, 2011). One measure of this change in atmospheric circulation is the Southern Annular Mode (SAM), described as the pressure difference between Antarctica $\left(65^{\circ} \mathrm{S}\right)$ and the latitude band at around $40^{\circ} \mathrm{S}$ (Karpechko et al., 2009; Marshall, 2003). Since the mid-1970s, SAM appears to have undergone a positive shift in the troposphere, which has been associated with hemispheric-wide changes in the atmosphere-ocean-ice domains, including precipitation patterns and significant surface and subsurface ocean warming (Cook et al., 2010; Delworth and Zeng, 2014; Domack et al., 2005; Gille, 2008, 2014; Thompson et al., 2011). This trend is projected to continue during the 21 st century as a result of both ongoing greenhouse gas emissions and a persistence of the Antarctic ozone hole (Liu and Curry, 2010; Thompson et al., 2011; Yin, 2005), potentially resulting in reduced Southern Ocean uptake of anthropogenic $\mathrm{CO}_{2}$ (Ito et al., 2010; Le Quére et 
al., 2009; Lenton et al., 2013; Marshall, 2003; Marshall and Speer, 2012).

While no observational records for SAM extend beyond the late 19th century (Fogt et al., 2009; Marshall, 2003; Visbeck, 2009), proxy records of past westerly airflow have been generated on annual-to-centennial timescales through the Holocene (Abram et al., 2014; Björck et al., 2012; Lamy et al., 2010; Lisé-Pronovost et al., 2015; McGlone et al., 2010; Strother et al., 2015; Villalba et al., 2012). Crucially, the association between proxies and changes in westerly wind strength and/or latitude is often implied but few provide a direct measure of past airflow or directly test their interpretation through time. One possibility is the identification of exotic airborne particles preserved in sedimentary sequences. Ideally, the peat or lake record should be close enough to the source to have a relatively high input of material (e.g. pollen, charcoal) but not so close that the influx is constant over time. Whilst numerous studies have been undertaken in the Arctic (Fredskild, 1984; Jessen et al., 2011) and the high latitudes of the Indian and Pacific oceans (McGlone et al., 2000; Scott and van Zinderen Barker, 1985), few have been reported from the South Atlantic. Recent work on a lake core taken from Annekov Island, South Georgia (Strother et al., 2015) demonstrates the considerable potential of this approach but the relatively large distance from the nearest source in South America (Fig. 1) (approximately $2100 \mathrm{~km}$ ) limits the delivery of pollen, with no charcoal reported.

Here we report a new high-resolution record of westerly airflow over the past 2600 years from the Falkland Islands. The Falkland Islands $\left(52^{\circ} \mathrm{S}\right)$ lie within the main latitudinal belt of Southern Hemisphere westerly airflow, 500 to $730 \mathrm{~km}$ east of Argentina and $1410 \mathrm{~km}$ west of Annekov Island. The close proximity to South America means that these islands receive a relatively high input of particles from the continental mainland (Barrow, 1978; Rose et al., 2012), making them an ideal location to investigate past changes in westerly airflow.

\section{Methods}

The Falkland Islands are a low-lying archipelago in the South Atlantic Ocean, situated in the furious fifties wind belt on the southeast South American continental shelf at $51-52^{\circ} \mathrm{S}, 58$ $61^{\circ} \mathrm{W}$ (Fig. 1). The Falkland Islands experience a cool temperate but relatively dry oceanic climate, dominated by westerly winds (Otley et al., 2008). Across the year, the temperature ranges from $2.2^{\circ} \mathrm{C}$ (July) to $9^{\circ} \mathrm{C}$ (February), with the islands receiving a relatively low but variable precipitation (typically ranging between 500 and $800 \mathrm{~mm}$ year $^{-1}$ ) lying in the lee of the Andes. Modern climate records show that the prevailing wind direction across the Falkland Islands is predominantly from the west with strong winds throughout the year, with no significant seasonal variation (Upton and Shaw, 2002).

Climate amelioration following the Last Glacial Maximum led to the establishment of blanket peat across large parts of the islands from 16500 cal. years BP (Wilson et al., 2002). To investigate past westerly airflow in the late Holocene, an exposed ericaceous-grass peatland was cored on Canopus Hill, above Port Stanley Airport $\left(51.691^{\circ} \mathrm{S}\right.$, $57.785^{\circ} \mathrm{W}$, approximately $30 \mathrm{~m}$ above sea level) (Fig. 1). The one-metre sequence reported here comprises a uniform darkbrown peat from which the uppermost $90 \mathrm{~cm}$ was contiguously sampled for pollen, charcoal and comprehensive dating.

Pollen samples were prepared using standard palynological techniques (Faegri and Iverson, 1975). Volumetric samples were taken every $1 \mathrm{~cm}$ along the core and Lycopodium spores were added as a "spike". The samples were deflocculated with hot $10 \% \mathrm{NaOH}$ and then sieved through a $106 \mu \mathrm{m}$ mesh. The samples then underwent acetolysis, to remove extraneous organic matter before the samples were mounted in silicon oil. Pollen types/palynomorphs were counted at $400 \times$ magnification until a minimum of 300 target grains were identified. The pollen counts were expressed as percentages, with only terrestrial land pollen (TLP) contributing to the final pollen sum. Pollen/palynomorphs were identified using standard pollen keys (Barrow, 1978; Macphail and Cantrill, 2006) and the pollen type slide collection at Exeter University. Past fire activity was assessed using microcharcoal counts of fragments $(<106 \mu \mathrm{m})$ identified on the pollen slides (Whitlock and Larsen, 2001). Counts were undertaken at each level until a fixed total of 50 lycopodium spores were counted and the total expressed as a concentration (fragments per $\mathrm{cm}^{3}$ ). More than $99 \%$ of charcoal fragments were less than $50 \mu \mathrm{m}$ in size, with negligible amounts identified in the $50-106 \mu \mathrm{m}$ and $>106 \mu \mathrm{m}$ fractions.

Terrestrial plant macrofossils (fruits and leaves) were extracted from the peat sequence and given an acid-base-acid (ABA) pretreatment and then combusted and graphitised in the University of Waikato AMS laboratory, with ${ }^{14} \mathrm{C} /{ }^{12} \mathrm{C}$ measurement by the University of California at Irvine (UCI) on a NEC compact (1.5SDH) AMS system. The pretreated samples were converted to $\mathrm{CO}_{2}$ by combustion in sealed prebaked quartz tubes, containing $\mathrm{Cu}$ and $\mathrm{Ag}$ wire. The $\mathrm{CO}_{2}$ was then converted to graphite using $\mathrm{H}_{2}$ and an Fe catalyst, and loaded into aluminium target holders for measurement at UCI. This was supplemented by ${ }^{137} \mathrm{Cs}$ measurements down the profile to detect the onset of nuclear tests. ${ }^{137} \mathrm{Cs}$ analysis was undertaken following standard techniques with measurements made using an ORTEC high-resolution, lowbackground coaxial germanium detector. Detectable measurements were obtained down to 8.5 and $9.5 \mathrm{~cm}$ and the lowest depth assigned an age of CE 1963, the time of early radionuclide fallout at these latitudes (Hancock et al., 2011).

The radiocarbon and ${ }^{137} \mathrm{Cs}$ ages were used to develop an age model using a $\mathrm{P}_{-}$sequence deposition model in OxCal 
(a)

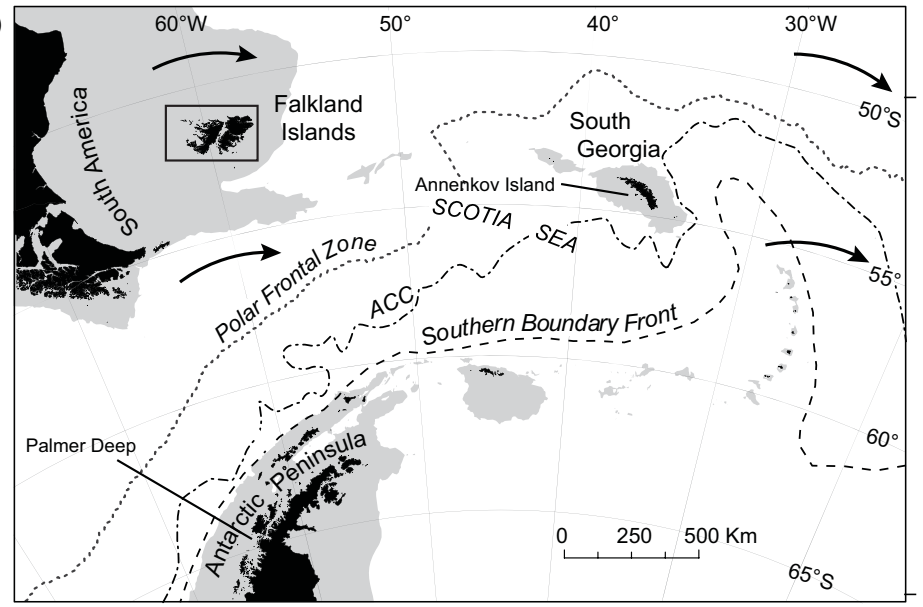

(b)

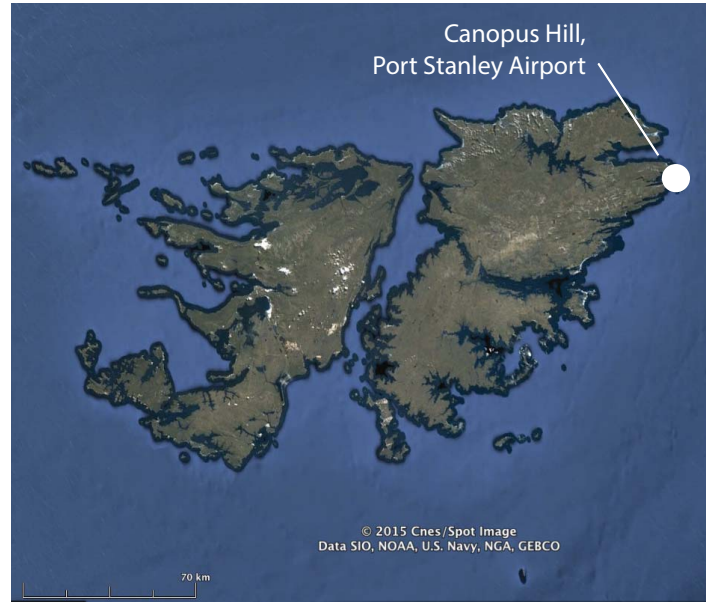

Figure 1. Location of the Falkland Islands in the South Atlantic Ocean with mean locations of the Polar and Southern Boundary fronts (dashed lines), the continental shelf (grey areas), and prevailing westerly airflow (solid arrows) (a); and Canopus Hill, Port Stanley Airport, in the east Falkland Islands (b). (a) was modified from Strother et al. (2015) and (b) was obtained from Google Earth.

Table 1. Radiocarbon and modelled calibrated ages using SHCal13 (Hogg et al., 2013) and Bomb04SH (Hua and Barbetti, 2004) using the P_sequence and Outlier analysis option in OxCal 4.2 (Bronk Ramsey and Lee, 2013; Ramsey, 2008).

\begin{tabular}{ccccc}
\hline $\begin{array}{c}\text { Depth, } \\
\mathrm{cm}\end{array}$ & $\begin{array}{c}\text { Wk lab } \\
\text { number }\end{array}$ & Material & $\begin{array}{c}\% \mathrm{M} /{ }^{14} \mathrm{C} \\
(\mathrm{BP} \pm 1 \sigma)\end{array}$ & $\begin{array}{c}\text { Modelled years } \\
(\mathrm{BP} \pm 1 \sigma)\end{array}$ \\
\hline $8-9$ & 34598 & Fruits and leaves & $117.0 \pm 0.4 \% \mathrm{M}$ & $-16 \pm 11$ \\
$11-12$ & 32994 & Fruits and leaves & $107.8 \pm 0.4 \% \mathrm{M}$ & $-8 \pm 2$ \\
$18-19$ & 37007 & Fruits and leaves & $107.3 \pm 0.3 \% \mathrm{M}$ & $3 \pm 31$ \\
$25-26$ & 35146 & Fruits and leaves & $95 \pm 25$ & $94 \pm 66$ \\
$35-36$ & 37008 & Fruits and leaves & $647 \pm 25$ & $603 \pm 29$ \\
$39-40$ & 33445 & Fruits and leaves & $761 \pm 25$ & $661 \pm 28$ \\
$57-58$ & 32996 & Fruits and leaves & $1818 \pm 25$ & $1672 \pm 51$ \\
$70-71$ & 32350 & Fruits and leaves & $2235 \pm 25$ & $2201 \pm 67$ \\
$97-98$ & 32997 & Fruits and leaves & $2749 \pm 25$ & $2802 \pm 32$ \\
\hline
\end{tabular}

4.2 (Bronk Ramsey, 2008) with General Outlier analysis detection (probability $=0.05)$ (Bronk Ramsey, 2011). The ${ }^{14} \mathrm{C}$ ages were calibrated against the Southern Hemisphere calibration (SHCal13) data set. Using Bayes' theorem, the algorithms employed sample possible solutions with a probability that is the product of the prior and likelihood probabilities. Taking into account the deposition model and the actual age measurements, the posterior probability densities quantify the most likely age distributions; the outlier option was used to detect ages that fall outside the calibration model for each group, and if necessary, down-weight their contribution to the final age estimates. Modelled ages are reported here as thousands of calendar years BP or cal. BP (Table 1 and Fig. 2). The pollen sequence reported here spans the last 2600 years with an average 30-year resolution (Fig. 3).

To investigate the periodicities preserved in the palaeoenvironmental proxies utilised herein, we undertook MultiTaper Method (MTM) analysis using a narrowband signal, red noise significance and robust noise background estima- tion (with a resolution of 2 and 3 tapers) (Thomson, 1982). We also applied single spectrum analysis (SSA), which applies an empirical orthogonal function (EOF) analysis to the autovariance matrix on the chronologies. Here we undertook a Monte Carlo significance test (95\% significance), using a window of 9, a Burg covariance, and eight components. Both analyses used the software $k$ Spectra version 3.4.3 (3.4.5). Wavelet analysis and coherence was undertaken on the 30-year averaged data using the $w t()$ and wtc () functions respectively in the R package "Biwavelet" (Gouhier, 2013). The Morlet continuous wavelet transform was applied, and the data were padded with zeros at each end to reduce wraparound effects (Torrence and Webster, 1999). To test the robustness of the obtained periodicities, the LombScargle algorithm was employed, a spectral decomposition method that computes the spectral properties of time series with irregular sampling intervals (Ruf, 1999) - in this instance, the "raw" charcoal values. This method minimises bias and induced periodicities that may arise from interpolating missing or unevenly spaced data. The technique was undertaken using the lsp() function within the "lomb" R package. Periodicities were extracted from data sets using Analyseries (Paillard et al., 1996).

A measure of solar variability was derived by calculating the ${ }^{14} \mathrm{C}$ production rate using the IntCal13 atmospheric radiocarbon data set (Reimer et al., 2013) and an oceanatmosphere box diffusion model (Oeschger et al., 1975); the same as that reported in previous studies (Bond et al., 2001; Turney et al., 2005). The model consists of one box for the atmosphere, one for the ocean mixed layer, 37 boxes for the thermocline, five boxes for the deep ocean and two for the biosphere (short and long residence time) (Stuiver and Braziunas, 1993a). The climate-influenced mixing parameters (air-gas sea exchange, eddy diffusivity, and biospheric 


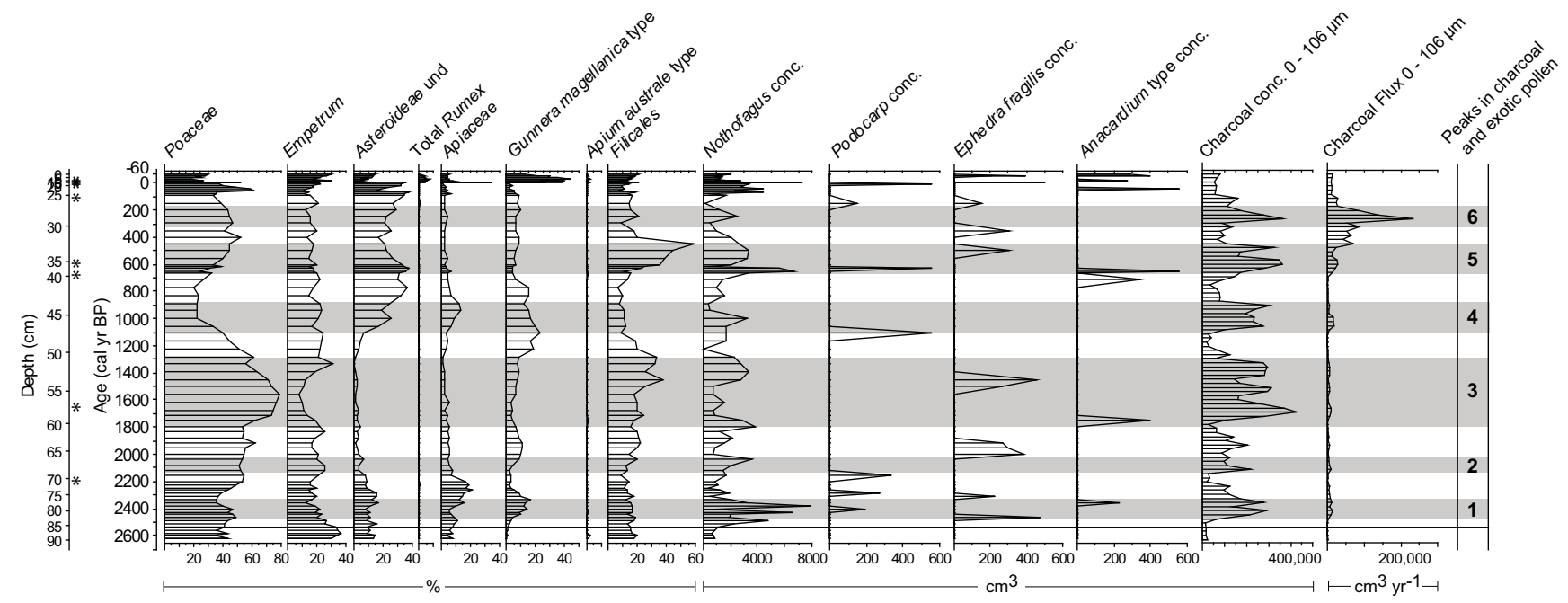

Figure 2. Pollen diagram from Canopus Hill, Port Stanley Airport, plotted against depth and calendar age. The location of ${ }^{137} \mathrm{Cs}$ and ${ }^{14} \mathrm{C}$ ages are marked by asterisk.

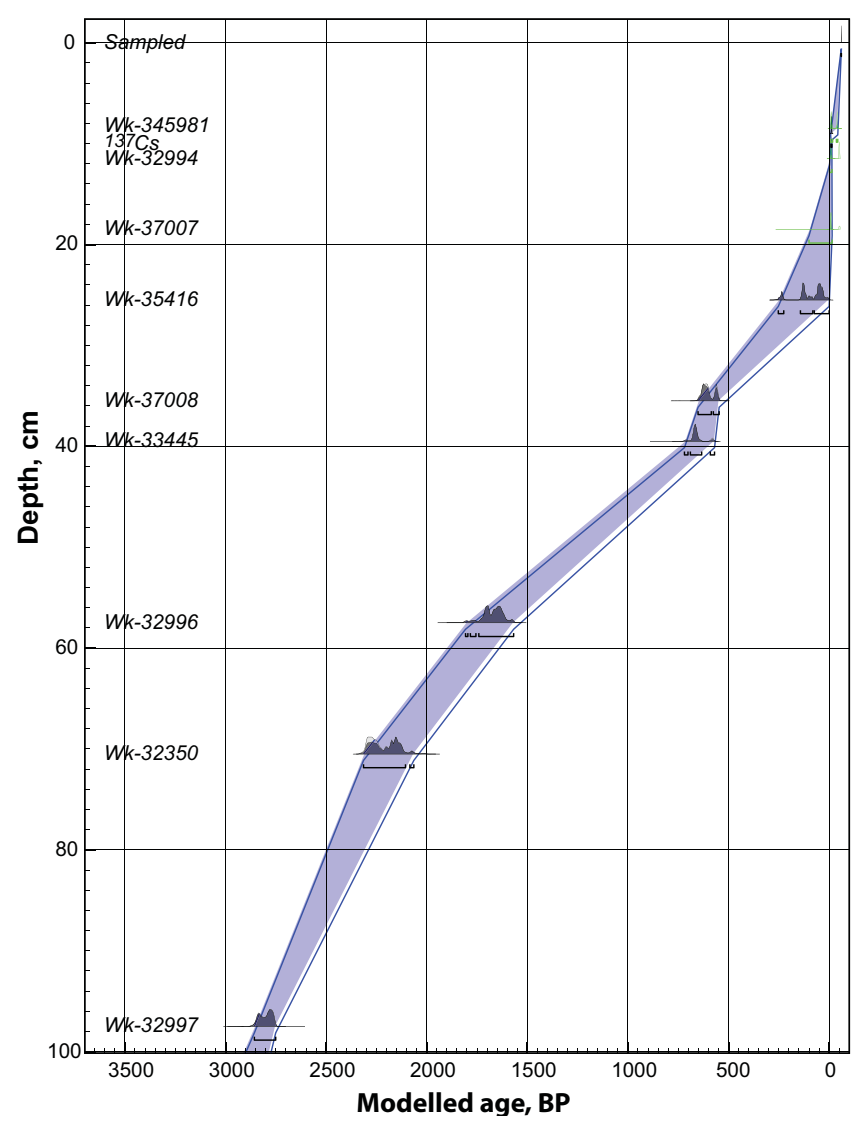

Figure 3. Age-depth plot for Canopus Hill, Port Stanley Airport, with $1 \sigma$ age range (blue envelope) and probability distributions.

uptake and release) were held constant through the run using the same setup as Marine04 (Table 2) (Hughen et al., 2004). The model was parametrised to produce a pre-industrial ma- rine mixed layer ${ }^{14} \mathrm{C}$ of $-46.5 \%$ and a deep ocean value of $-190 \%$ at CE 1830 for the 2013 marine calibration data set Marine13 (Reimer et al., 2013).

\section{Results and discussion}

Only a limited number of Holocene pollen records have been reported from the Falkland Islands (Barrow, 1978). The pollen record in the uppermost $90 \mathrm{~cm}$ at Canopus Hill is dominated by Poaceae and Empetrum, consistent with previous work and today's vegetation (Barrow, 1978; Broughton and McAdam, 2003; Clark et al., 1998). The most significant change in the pollen taxa is a pronounced shift to increased representation of Asteroideae (accompanied by a relative decline in Poaceae) centred on $47 \mathrm{~cm}$ (equivalent to $1100 \mathrm{cal}$. BP) (Fig. 2). Although undifferentiated in the counts, the Asteroideae are most likely Chilliotrichum diffusum, common on the island across a range of habitats including Empetrum heath (Broughton and McAdam, 2003). The shift in the pollen diagram therefore most likely reflects the replacement of upland grasslands by Empetrum heath. Highly variable charcoal counts were obtained through the sequence $(<106 \mu \mathrm{m})$ (Fig. 2), with negligible macrocharcoal fragments $(>106 \mu \mathrm{m})$ identified, suggesting there was little or no fire on the site.

The exotic pollen taxa were expressed as concentration values to explore their changing input onto the site over the last 2600 years (Fig. 2). Although these data could be reexpressed as a pollen influx, the interpretation of flux data in non-annually laminated sequences can be strongly influenced by the choice of age model and the density of dated points down the core (Davis, 1969; Hicks and Hyvärinen, 1999). Consideration of the radiocarbon and ${ }^{137} \mathrm{Cs}$ ages (Table 1) suggests that the depth-age relationship can be de- 
Table 2. Box diffusion model parameters for Marine98 (Bond et al., 2001; Turney et al., 2005) vs. Marine04 (Hughen et al., 2004).

\begin{tabular}{|c|c|c|}
\hline Parameter & Marine98 & Marine04 \\
\hline Air-gas sea exchange & 19 moles $^{-2}$ years $^{-1}$ & 18.8 moles $^{-2}$ years $^{-1}$ \\
\hline Eddy diffusivity & $4000 \mathrm{~m}^{2}$ years ${ }^{-1}$ & $4220 \mathrm{~m}^{2}$ years $^{-1}$ \\
\hline Pre-industrial atmospheric $\left[\mathrm{CO}_{2}\right]$ & $280 \mathrm{ppm}$ & $270 \mathrm{ppm}$ \\
\hline Initial atmospheric $\Delta^{14} \mathrm{C}$ & $90 \%$ & $100 \%$ \\
\hline
\end{tabular}

(a)

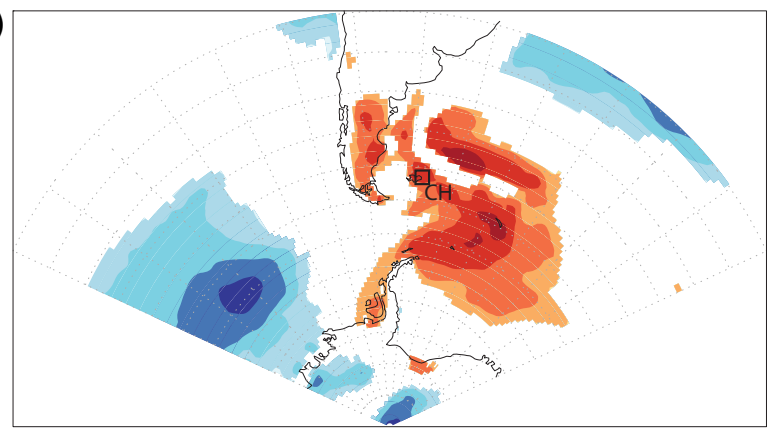

(b)

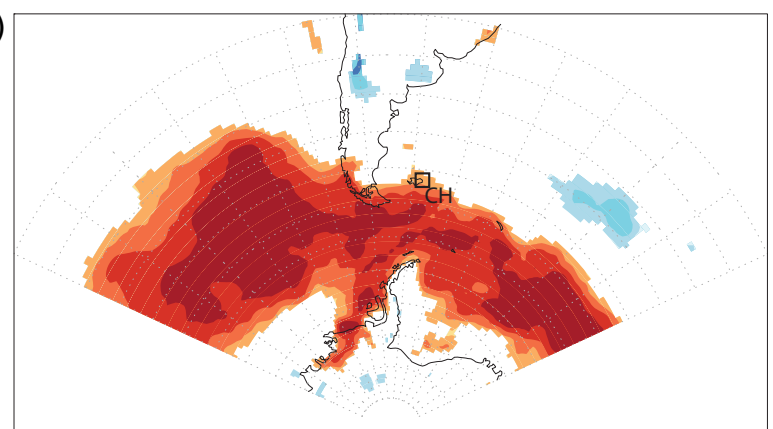

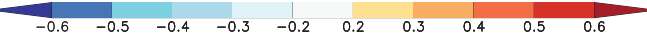

Figure 4. Correlation of relationship between the hemispherically averaged Southern Annular Mode (SAM) index (Marshall, 2003) with 2-10 m air temperature (a) and wind strength (b) in the ERA-79 Interim reanalysis (Dee et al., 2011) (July-June, 1979-2013). Location of Canopus Hill, (CH), Falkland Islands, shown. Analyses were made with KNMI Climate Explorer (van Oldenborgh and Burgers, 2005).

scribed by a linear relationship $\left(r^{2}=0.98\right)$ below a depth of $18 \mathrm{~cm}$ (Fig. 3). This means that the pollen (and charcoal) concentration data below this depth are equivalent to influx. In the uppermost section of the core (above $18 \mathrm{~cm}$ ) a faster rate of sediment accumulation (or less compaction) means that the deposition time is reduced.

Importantly, the sequence preserves a record of exotic pollen delivery into the site, with Nothofagus dominating the input but with trace amounts of Podocarp, Ephedra fragilis, and Anacardium-type pollen ( $<0.5 \%$ total land pollen), all originating from South America. Whilst the low levels of most exotic pollen precludes meaningful interpretation, all samples contain Nothofagus ( $<5 \%$ total land pollen), a taxa not known to have grown on the Falkland Islands since the Middle Miocene/Early Pliocene (Macphail and Cantrill, 2006) but which has been detected in Lateglacial (Clark et al., 1998) and Holocene (Barrow, 1978) sequences. Producing relatively small pollen grains $(20-40 \mu \mathrm{m}$ in diameter) (Wang et al., 2000), the nearest source of contemporary Nothofagus is South America which extends from $33^{\circ} \mathrm{S}$ in central Chile to $56^{\circ} \mathrm{S}$ on Tierra del Fuego (Veblen et al., 1996). The youngest arboreal macrofossils of the other exotic taxa are dated to late Tertiary deposits on West Point Island, West Falkland (Birnie and Roberts, 1986).

Whilst exotic pollen values are relatively low, peaks in Nothofagus coincide with increased amounts of charcoal in the Canopus Hill sequence. Importantly, negligible amounts of macro-charcoal $(>106 \mu \mathrm{m})$ were identified, suggesting that the charcoal has been blown to the site from Patagonia. The aerial delivery of the charcoal to the Falkland Islands is supported by the close correspondence with charcoal in Laguna Guanaco in Southwest Patagonia $\left(51^{\circ} \mathrm{S}\right.$ ) (Moreno et al., 2009). Importantly, Nothofagus dominates lowland Patagonian vegetation and, in areas away from human activity, was established by 5000 cal. years BP (Iglesias et al., 2014; Kilian and Lamy, 2012), with a stepped expansion in Nothofagus at Laguna Guanaco centred on $570 \mathrm{cal}$. BP (Moreno et al., 2009) and evidence for temporary forest fragmentation during periods of stronger westerly airflow (Moreno et al., 2014). In marked contrast to Patagonia, the Falklands Nothofagus pollen record is highly variable and of sufficient concentration to recognise similar changes to those in the charcoal record, with periods of high fire frequency associated with high input of exotic pollen.

Although charcoal fragments less than $106 \mu \mathrm{m}$ might reflect fire in the local environment, charcoal of this size can be transported long distances (Clark, 1988). The vast majority of the charcoal fragments are less than $50 \mu \mathrm{m}$, comparable in size to exotic Nothofagus $(20-40 \mu \mathrm{m})$ and Podocarpus (40-50 $\mu \mathrm{m}$ in diameter) pollen (Wang et al., 2000; Wilson and Owens, 1999). The close correspondence between the Nothofagus pollen record and charcoal fragments in the Canopus Hill sequence on the Falkland Islands strongly suggests similar sources, indicating that the higher charcoal counts provide a more robust measure of the westerly airflow. A sustained period of charcoal delivery to the Falk- 

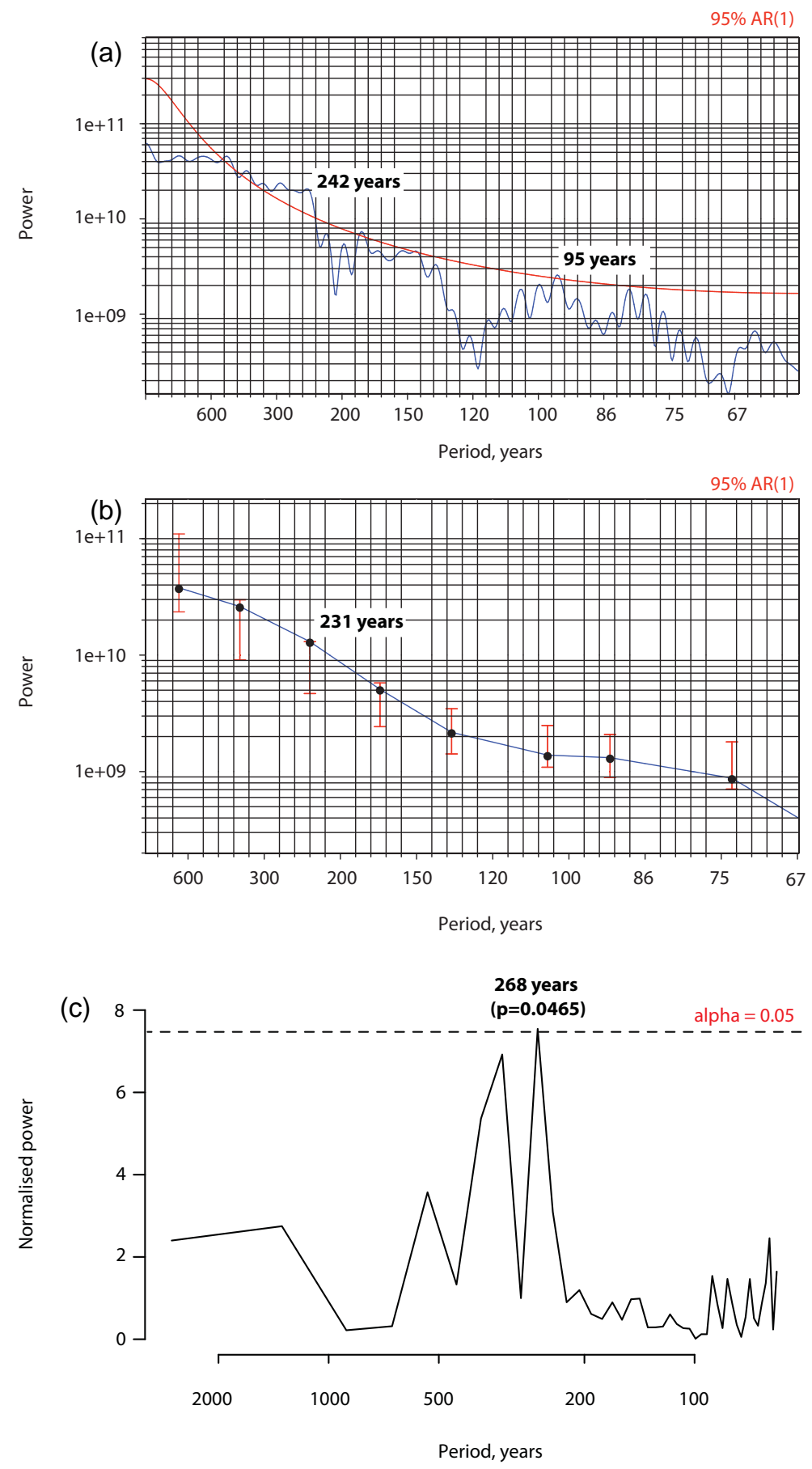

Figure 5. Multi-taper method (MTM) (a), Monte Carlo single spectrum analysis (SSA) analyses (b) and Lomb-Scargle analysis (c) of charcoal from the Canopus Hill sequence. Error bars denote $95 \%$ confidence.

land Islands is observed between 2000 and $1000 \mathrm{cal}$. BP, with prominent peaks in Nothofagus and charcoal recognised at approximately 2400, 2100, 1800-1300, 1000, 550, and $250 \mathrm{cal}$. BP (Fig. 2) which we interpret here as stronger westerly wind flow. Our results suggest that reports of preEuropean human activity on the Falkland Islands as inferred by the presence of charcoal in peat sequences (Buckland and Edwards, 1998) may be premature.

In contrast to work at Annenkov Island which reported enhanced westerly airflow is associated with wetter conditions (Strother et al., 2015), we observe the reverse on the Falkland Islands. Modern comparisons between the SAM (as a 

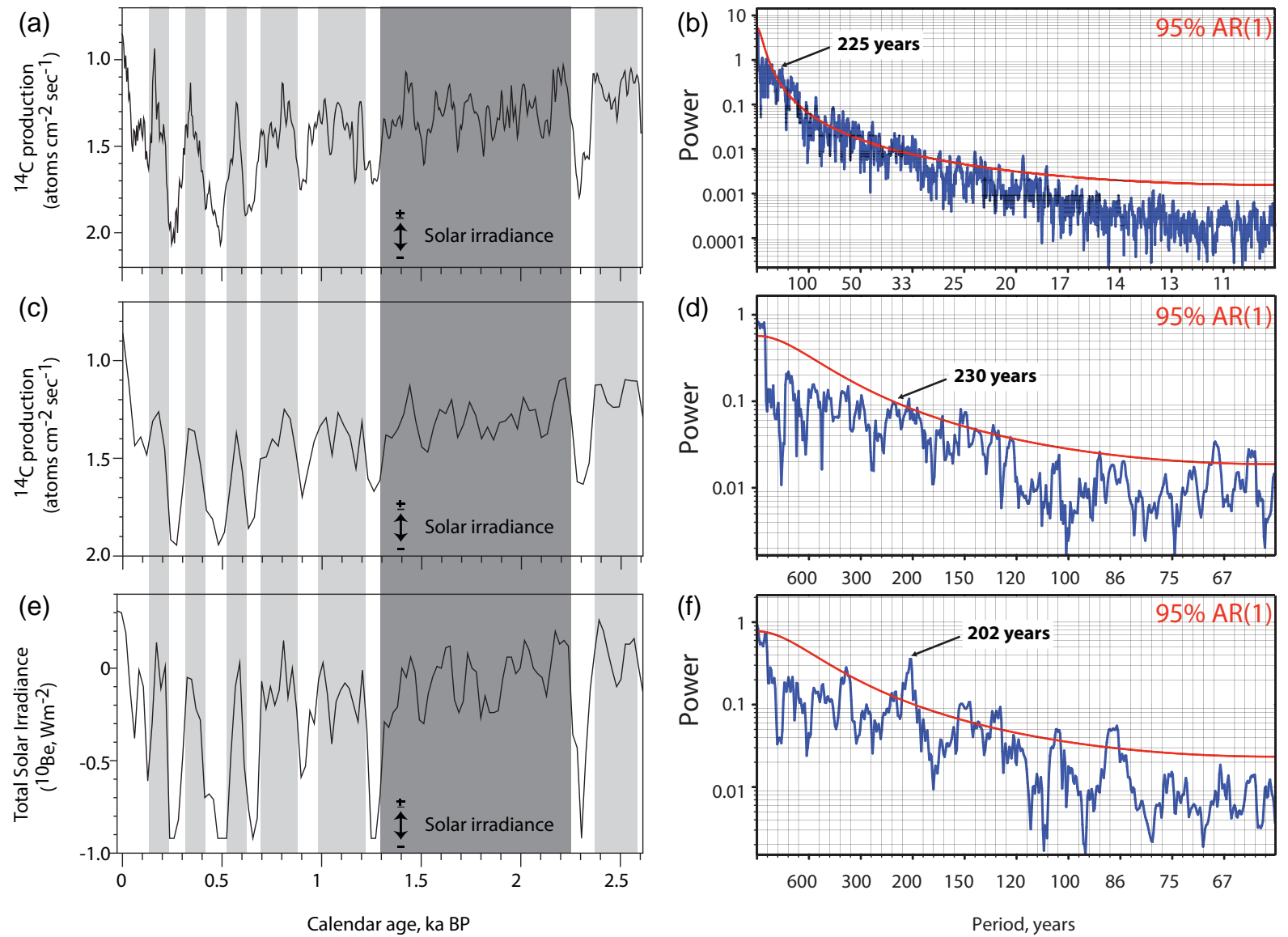

Figure 6. Changes in solar output and multi-taper method (MTM) analysis of reconstructed radiocarbon $\left({ }^{14} \mathrm{C}\right)$ production rate $(5$-year resolution; this study) (Bond et al., 2001; Turney et al., 2005) (a, b), ${ }^{14} \mathrm{C}$ production rate (resampled at 30 years) (c, d), and Total Solar Irradiance (based on polar ice ${ }^{10} \mathrm{Be}$ ) (resampled at 30 years) (e, f) (Steinhilber et al., 2009) for the full length of each record. The dark grey column defines a millennial-duration period of sustained high solar irradiance in all records; the light grey columns define temporary (centennial-duration) periods of high irradiance. The periodicities that fall within the reported range of the de Vries cycle are identified in the MTM panels (200-230 years).

measure of westerly airflow) (Marshall, 2003) and air temperature suggest a positive correlation (Abram et al., 2014). Comparing historic observations of SAM with ERA79 Interim reanalysis (Dee et al., 2011), we observe a highly significant relationship with more positive phases of SAM associated with warmer $2-10 \mathrm{~m}$ height air temperatures and wind speeds across much of South America, the Antarctic Peninsula, and the Falkland Islands (Fig. 4), supporting our interpretation. The contrasting moisture interpretation to that in South Georgia may be a result of the rain shadow effect of the Andes on the Falklands. It should be noted, however, that the reanalysis product used here is only for the period commencing CE 1979 (the satellite era) and that different atmospheric dynamics may have been involved in the delivery of exotic pollen and charcoal to the Falkland Islands on centennial timescales.

The MTM analysis identifies two different periodicities in the charcoal record $(<106 \mu \mathrm{m})$ from Canopus Hill significant above $95 \%-242$ and 95 years, with the former exhibiting a broad multi-decadal peak (Fig. 5a). To test whether the MTM spectral peak is robust, we undertook SSA on the sequence chronologies. A Monte Carlo significance test identified a significant periodicity (above $95 \%$ ) at 231 years (Fig. 5b). Furthermore, the Lomb-Scargle algorithm identified a 268year peak (Fig. 5c), indicating that this periodicity is pervasive through the record regardless of the sampling method, and therefore robust.

The existence of a 200-250-year periodicity has been identified in numerous Holocene records globally (Galloway et al., 2013; Poore et al., 2004), including Southern Ocean productivity as recorded in Palmer Deep (Domack et al., 2001; Leventer et al., 1996) and dust deposition over Antarctica (Delmonte et al., 2005). Furthermore, whilst no spectral analysis was undertaken, a series of recurring 200-year long dry/warm periods have recently been reported from Patagonia over the last three millennia and linked to positive SAM- 


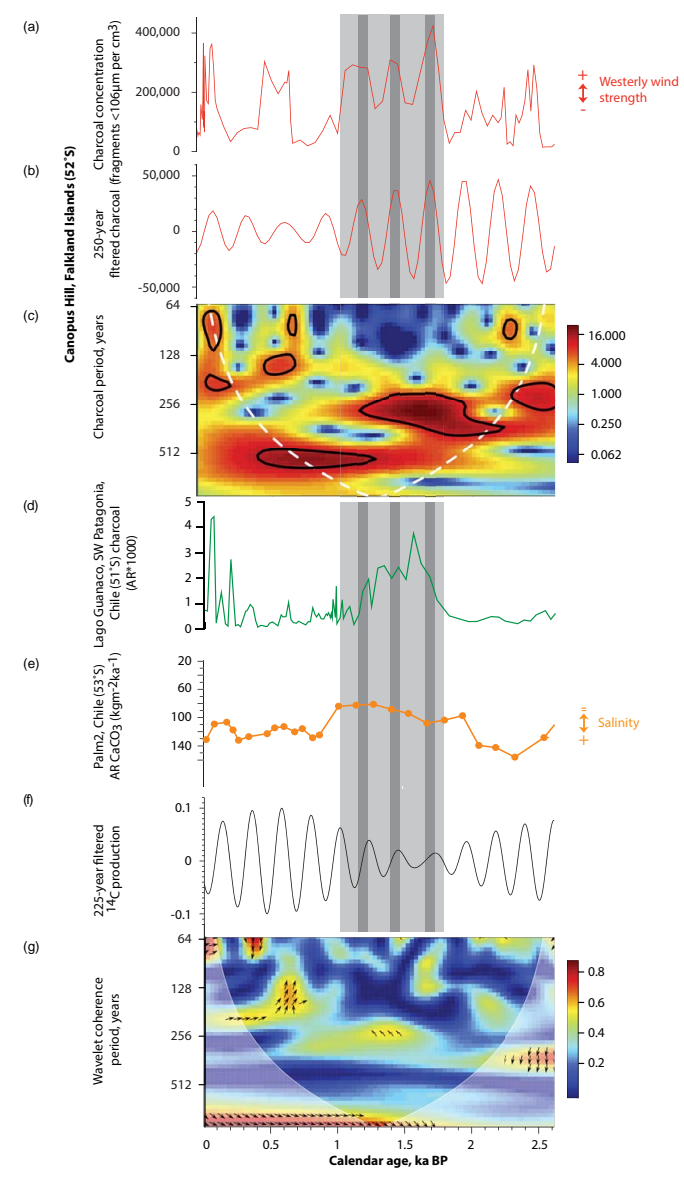

Figure 7. Charcoal concentration $(<106 \mu \mathrm{m})(\mathbf{a})$, Gaussian-filtered charcoal in the 250 -year band $\left(250 \pm 25\right.$ years $\left.^{-1}\right)(\mathbf{b})$, and wavelet analysis of charcoal concentration (c) from Canopus Hill, Port Stanley Airport $\left(52^{\circ} \mathrm{S}\right)$. Solid black line in wavelet denotes $95 \%$ confidence in periodicity; white dashed line denotes cone of influence. (d) Charcoal concentration data from Laguna Guanaco, Chile $\left(51^{\circ} \mathrm{S}\right)$ (Moreno et al., 2009); (e) the biogenic carbonate accumulation rate (AR) from Palm2, Chile $\left(53^{\circ} \mathrm{S}\right)$. Gaussian-filtered ${ }^{14} \mathrm{C}$ in the 225-year band $\left(225 \pm 22.5\right.$ years $\left.^{-1}\right)$ are plotted in (f), and wavelet coherence between the 30 -year sampled charcoal and ${ }^{14} \mathrm{C}$ production in (g); white dashed line denotes cone of influence; arrows pointing up indicate that ${ }^{14} \mathrm{C}$ production (solar) leads Falkland Islands charcoal (proxy of Southern Hemisphere westerly strength). The dark grey columns define peaks in charcoal 250-year periodicity lagging minima in ${ }^{14} \mathrm{C}$ production rate (high solar irradiance); the light grey area describes the period of pervasively stronger winds across the South Atlantic 2000 to 1000 cal. BP.

like conditions (Moreno et al., 2014). The origin of the $\sim 250$ years periodicity may be linked to postulated centennialscale changes in climate modes of variability including the El Niño Southern Oscillation (ENSO) (Ault et al., 2013) or Southern Ocean convection (Martin et al., 2013). Importantly, a 200-250-year periodicity has also been observed in records of atmospheric ${ }^{14} \mathrm{C}$ and ${ }^{10} \mathrm{Be}$ (Adolphi et al., 2014; Steinhilber et al., 2012; Stuiver and Braziunas, 1993b; Tur- ney et al., 2005), suggesting that the so-called de Vries solar cycle may play a role (Leventer et al., 1996).

The detection of solar forcing in palaeo records is highly sensitive to the chronological framework being investigated (Gray et al., 2010). To explore the possible role of solar variability on Southern Hemisphere westerly airflow we first analysed the modelled production rate of ${ }^{14} \mathrm{C}$ derived from 5-year resolved tree-ring data (Reimer et al., 2013), a cosmogenic radionuclide that is produced in the upper atmosphere (with ${ }^{14} \mathrm{C}$ increasing with reduced solar activity) (Bond et al., 2001; Turney et al., 2005). We resampled the ${ }^{14} \mathrm{C}$ data set at 30-year resolution to mimic the resolution of the Canopus Hill sequence and compared these data to the Total Solar Irradiance (TSI) generated from the polar ice core ${ }^{10} \mathrm{Be}$ which is reported at a 20-30-year resolution (Steinhilber et al., 2009) (Fig. 6). Regardless of the data set used, the same pattern is observed with large amplitude changes in solar irradiance between 2600 and 2300 years ago and from 1300 cal. years BP to present day, but with sustained high irradiance between 2300 and 1300 cal. years BP (Fig. 6a, c and e). We find that the 5-year resolved IntCal13 data set produces a periodicity comparable to the Falkland Islands record (225 years at $99 \%$ confidence; Fig. 6a and b). Importantly, when we look at the downscaled records of solar irradiance, the statistical significance decreases in the lower-resolved ${ }^{14} \mathrm{C}$ data set (230 years at $90 \%$; Fig. 6c and d) or shifts to a lower frequency in the ${ }^{10} \mathrm{Be}$ record (202 years at $99 \%$; Fig. 6e and f).

Our results imply that the central Southern Hemisphere westerlies were particularly strong between 2000 and $1000 \mathrm{cal}$. BP and/or lay close to the latitude of the Falkland Islands - at least within the South American sector and possibly hemispheric-wide (Turney et al., 2016) (Fig. 7). Records of comparable latitude and age from South America are Laguna Guanaco $\left(51^{\circ} \mathrm{S}\right.$ ) (Moreno et al., 2014) and Palm2 $\left(53^{\circ} \mathrm{S}\right)$ (Lamy et al., 2010). The Laguna Guanaco record captures a remarkably similar fire history as preserved in the Canopus Hill with a pronounced peak in charcoal over the same period (Fig. 7d). In Palm2, accumulation rates of biogenic carbonate provide a proxy for salinity changes in surface fjord waters off the west coast of Chile with lower salinities associated with strong winds and relatively high precipitation, limiting the influence of the open ocean water and reducing biogenic carbonate production. While the data set from Palm2 does not have the resolution of the other records, a similar trend with pervasive lower salinities (stronger westerly winds) is recorded between 2000 and 1000 cal. years BP (Fig. 7e). Whilst the change in the trend may be interpreted as reflecting either a change in the latitude and/or strength of the winds, the parallel peaks and troughs in Nothofagus and charcoal from Canopus Hill (in contrast to constant Nothofagus levels at Laguna Guanaco - Moreno et al., 2009) imply that the core latitude of the westerly winds has not changed and instead was particularly strong between 2000 and 1000 cal. years BP, resulting in increased fire frequency in Patagonia (Holz and Veblen, 2012). This is supported by 
a study on Patagonian Fitzroya cupressoides from $40-42^{\circ} \mathrm{S}$ (Roig et al., 2001). Whilst a living series spanning 1229 years did not identify a 200-250-year periodicity, a 245-year cycle was identified in a floating 50000-year-old tree ring series of comparable length, consistent with our record suggesting a suppression of this periodicity across a large latitudinal range over the last 1000 years. Importantly, the $\sim 250$-year periodicity identified in the charcoal record varies in amplitude over the last 2600 years (Fig. 7a-c). A Gaussian filtered curve and wavelet plot shows the $\sim 250$ year periodicity is expressed between 2600 and $1000 \mathrm{cal}$. BP, and spans the prominent (sustained) peak in charcoal, with an implied reduction in the expression of the $\sim 250$-year periodicity over the last millennium.

The role that changing solar output may have on westerly airflow is not immediately apparent. The strongest inferred winds fall within a millennial-duration period of high solar irradiance (Fig. 6). In spite of the relatively muted amplitude of the 225-year periodicity in the ${ }^{14} \mathrm{C}$ record, wavelet coherence with the charcoal data sampled at 30-year resolution shows coherency centred on 1500 cal. years BP (Fig. 7g), with the proxy of solar irradiance leading westerly wind strength (arrows up). Furthermore, we observe peaks in solar irradiance leading charcoal by of the order of 20-40 years (Fig. 7f), suggesting that Southern Hemisphere westerly winds may be particularly sensitive to the de Vries cycle during periods of high solar irradiance and less sensitive with reduced solar output. How solar periodicity may influence the strength of Southern Hemisphere westerly airflow is not precisely known. One possibility is that the $\sim 250$-year periodicity may change salinity in the North Atlantic (Stuiver and Braziunas, 1993b), driving changes in the Meridional Overturning Circulation that are transmitted globally. However, the existence of the same periodicity in the delivery of dust onto the East Antarctic Ice Sheet (Delmonte et al., 2005) does imply a direct atmospheric link, either through changing sea ice extent or sea surface temperatures, or via the westerlies themselves (Shindell et al., 1999). Recent work has highlighted the role of high solar irradiance in increasing tropospherestratosphere coupling, extending the seasonal length during which stronger Southern Hemisphere westerly winds are experienced at the surface (Kuroda and Yamazaki, 2010), similar to that observed in the Northern Hemisphere (Ineson et al., 2011). Alternatively, recent modelling work suggests that insolation changes can lead to increased "baroclinicity" (Fogwill et al., 2015) or a "Split Jet" (Chiang et al., 2014), strengthening westerly winds. Further work is required to understand the driving mechanism(s) behind the $\sim 250$-year periodicity on global climate.

\section{Conclusions}

Southern Hemisphere westerly airflow is believed to play a significant role in precipitation, sea ice extent, sea surface temperatures and the carbon cycle across the mid- to high latitudes. Unfortunately, the observational record only extends back to the late 19th century, limiting our understanding of what drives past changes in westerly winds. Although proxies of westerly airflow can provide long-term perspectives on past change, few provide a direct (passive) measure of westerly winds. Exotic pollen and charcoal fragments sourced upwind of sedimentary sequences can potentially provide a valuable insight into past variability. Here we report a new, comprehensively-dated high-resolution pollen record from a peat sequence on the Falkland Islands which lies under the present core of Southern Hemisphere westerly airflow and spanning the last 2600 years. We observe peaks in taxa from South America (particularly Nothofagus) and charcoal fragments $(<106 \mu \mathrm{m})$ that appear to be linked to warm and windy conditions. Spectral analysis identifies a robust $\sim 250$-year periodicity, with evidence of stronger westerly airflow between 2000 and 1000 cal. years BP. In comparison with other Southern Hemisphere records, the 250-year periodicity suggests that solar forcing plays a role in modulating the strength of the Southern Hemisphere westerlies, something hitherto not recognised. This will form the focus of future research.

Acknowledgements. C. S. M. Turney and C. Fogwill acknowledge the support of the Australian Research Council (FL100100195, FT120100004 and DP130104156). We thank the Falkland Islands Government for permission to undertake sampling on the island (permit number: R07/2011) and Darren Christie for assisting with the fieldwork. Many thanks to Joel Pedro and an anonymous reviewer for their insightful and constructive comments. The data are lodged on the NOAA Paleoclimate Archive.

The authors declare no competing financial interests.

Edited by: E. Brook

\section{References}

Abram, N. J., Mulvaney, R., Vimeux, F., Phipps, S. J., Turner, J., and England, M. H.: Evolution of the Southern Annular Mode during the past millennium, Nature Climate Change, 4, 564-569, 2014.

Adolphi, F., Muscheler, R., Svensson, A., Aldahan, A., Possnert, G., Beer, J., Sjolte, J., Bjorck, S., Matthes, K., and Thieblemont, R.: Persistent link between solar activity and Greenland climate during the Last Glacial Maximum, Nat. Geosci., 7, 662-666, 2014.

Ault, T. R., Deser, C., Newman, M., and Emile-Geay, J.: Characterizing decadal to centennial variability in the equatorial Pacific during the last millennium, Geophys. Res. Lett., 40, 3450-3456, 2013.

Barrow, C.: Postglacial pollen diagrams from south Georgia (subAntarctic) and West Falkland island (South Atlantic), J. Biogeogr., 5, 251-274, 1978.

Birnie, J. F. and Roberts, D. E.: Evidence of Tertiary forest in the Falkland Islands (Ilas Malvinas), Palaeogeogr. Palaeocl., 55, 4553,1986 . 
Björck, S., Rundgren, M., Ljung, K., Unkel, I., and Wallin, ̊̊.: Multi-proxy analyses of a peat bog on Isla de los Estados, easternmost Tierra del Fuego: a unique record of the variable Southern Hemisphere Westerlies since the last deglaciation, Quaternary Sci. Rev., 42, 1-14, 2012.

Bond, G., Kromer, B., Beer, J., Muscheler, R., Evans, M. N., Showers, W., Hoffman, S., Lotti-Bond, R., Hajdas, I., and Bonani, G.: Persistent solar influence on North Atlantic climate during the Holocene, Science, 294, 2130-2136, 2001.

Bronk Ramsey, C. B.: Radiocarbon dating: revolutions in understanding, Archaeometry, 50, 249-275, 2008.

Bronk Ramsey, C. B.: Dealing with outliers and offsets in radiocarbon dating, Radiocarbon, 51, 1023-1045, 2011.

Bronk Ramsey, C. and Lee, S.: Recent and planned developments of the program OxCal, Radiocarbon, 55, 720-730, 2013.

Broughton, D. A. and McAdam, J. H.: The current status and distribution of the Falkland Islands pteridophyte flora, Fern Gazette, 17, 21-38, 2003.

Buckland, P. C. and Edwards, K. J.: Palaeoecological evidence for possible Pre-European settlement in the Falkland Islands, J. Archaeol. Sci., 25, 599-602, 1998.

Chiang, J. C., Lee, S.-Y., Putnam, A. E., and Wang, X.: South Pacific Split Jet, ITCZ shifts, and atmospheric North-South linkages during abrupt climate changes of the last glacial period, Earth Planet. Sc. Lett., 406, 233-246, 2014.

Clark, R., Huber, U. M., and Wilson, P.: Late Pleistocene sediments and environmental change at Plaza Creek, Falkland Islands, South Atlantic, J. Quaternary Sci., 13, 95-105, 1998.

Clark, J. S.: Particle motion and the theory of charcoal analysis: source area, transport, deposition, and sampling, Quaternary Res., 30, 67-80, 1988.

Cook, A. J., Poncet, S., Cooper, A. P. R., Herbert, D. J., and Christie, D.: Glacier retreat on South Georgia and implications for the spread of rats, Antarct. Sci., 22, 255-263, 2010.

Davis, M. B.: Climatic changes in southern Connecticut recorded by pollen deposition at Rogers Lake, Ecology, 50, 409-422, 1969.

Dee, D. P., Uppala, S. M., Simmons, A. J., Berrisford, P., Poli, P., Kobayashi, S., Andrae, U., Balmaseda, M. A., Balsamo, G., Bauer, P., Bechtold, P., Beljaars, A. C. M., van de Berg, L., Bidlot, J., Bormann, N., Delsol, C., Dragani, R., Fuentes, M., Geer, A. J., Haimberger, L., Healy, S. B., Hersbach, H., Hólm, E. V., Isaksen, L., Kållberg, P., Köhler, M., Matricardi, M., McNally, A. P., Monge-Sanz, B. M., Morcrette, J. J., Park, B. K., Peubey, C., de Rosnay, P., Tavolato, C., Thépaut, J. N., and Vitart, F.: The ERA-Interim reanalysis: configuration and performance of the data assimilation system, Q. J. Roy. Meteor. Soc., 137, 553-597, 2011.

Delmonte, B., Petit, J., Krinner, G., Maggi, V., Jouzel, J., and Udisti, R.: Ice core evidence for secular variability and 200-year dipolar oscillations in atmospheric circulation over East Antarctica during the Holocene, Clim. Dynam., 24, 641-654, 2005.

Delworth, T. L. and Zeng, F.: Regional rainfall decline in Australia attributed to anthropogenic greenhouse gases and ozone levels, Nat. Geosci., 7, 583-587, 2014.

Domack, E., Leventer, A., Dunbar, R., Taylor, F., Brachfeld, S., and Sjunneskog, C.: Chronology of the Palmer Deep site, Antarctic Peninsula: a Holocene palaeoenvironmental reference for the circum-Antarctic, The Holocene, 11, 1-9, 2001.
Domack, E., Duran, D., Leventer, A., Ishman, S., Doane, S., McCallum, S., Amblas, D., Ring, J., Gilbert, R., and Prentice, M.: Stability of the Larsen B ice shelf on the Antarctic Peninsula during the Holocene epoch, Nature, 436, 681-685, 2005.

Faegri, K. and Iverson, J.: Textbook of pollen analysis, Blackwell, Oxford, 340 pp., 1975.

Fogt, R. L., Perlwitz, J., Monaghan, A. J., Bromwich, D. H., Jones, J. M., and Marshall, G. J.: Historical SAM variability. Part II: Twentieth-Century variability and trends from reconstructions, observations, and the IPCC AR4 models, J. Climate, 22, 53465365, 2009.

Fogwill, C. J., Turney, C. S. M., Hutchinson, D. K., Taschetto, A. S., and England, M. H.: Obliquity control on Southern Hemisphere climate during the Last Glacial, Nature Scientific Reports, 5, 11673, doi:10.1038/srep11673, 2015.

Fredskild, B.: Holocene palaeo-winds and climatic changes in West Greenland as indicated by long-distance transported and local pollen in lake sediments, in: Climatic Changes on a Yearly to Millennial Basis, edited by: Mörner, N. A. and Karlén, W., Springer Netherlands, Dordrecht, The Netherlands, 1984.

Galloway, J. M., Wigston, A., Patterson, R. T., Swindles, G. T., Reinhardt, E., and Roe, H. M.: Climate change and decadal to centennial-scale periodicities recorded in a late Holocene NE Pacific marine record: Examining the role of solar forcing, Palaeogeogr. Palaeocl., 386, 669-689, 2013.

Gille, S. T.: Decadal-scale temperature trends in the Southern Hemisphere ocean, J. Climate, 21, 4749-4765, 2008.

Gille, S. T.: Meridional displacement of the Antarctic Circumpolar Current, Philos. T. Roy. Soc. A, 372, doi:10.1098/rsta.2013.0273, 2014.

Gillett, N. P., Stone, D. A., Stott, P. A., Nozawa, T., Karpechko, A. Y., Hegerl, G. C., Wehner, M. F., and Jones, P. D.: Attribution of polar warming to human influence, Nat. Geosci., 1, 750-754, 2008.

Gouhier, T.: biwavelet: Conduct univariate and bivariate wavelet analyses (Version 0.14), http://cran.r-project.org/web/packages/ biwavelet/index.html (last access: 12 January 2016), 2013.

Gray, L. J., Beer, J., Geller, M., Haigh, J. D., Lockwood, M., Matthes, K., Cubasch, U., Fleitmann, D., Harrison, G., Hood, L., Luterbacher, J., Meehl, G. A., Shindell, D., van Geel, B., and White, W.: Solar influences on climate, Rev. Geophys., 48, doi:10.1029/2009RG000282, 2010.

Hancock, G. J., Leslie, C., Everett, S. E., Tims, S. G., Brunskill, G. J., and Haese, R.: Plutonium as a chronomarker in Australian and New Zealand sediments: a comparison with ${ }^{137} \mathrm{Cs}$, J. Environ. Radioactiv., 102, 919-929, 2011.

Hicks, S. and Hyvärinen, H.: Pollen influx values measured in different sedimentary environments and their palaeoecological implications, Grana, 38, 228-242, 1999.

Hogg, A. G., Hua, Q., Blackwell, P. G., Niu, M., Buck, C. E., Guilderson, T. P., Heaton, T. J., Palmer, J. G., Reimer, P. J., Reimer, R. W., Turney, C. S. M., and Zimmerman, S. R. H.: SHCal13 Southern Hemisphere calibration, 0-50,000 years cal BP, Radiocarbon, 55, 1889-1903, 2013.

Holz, A. and Veblen, T. T.: Wildfire activity in rainforests in western Patagonia linked to the Southern Annular Mode, Int. J. Wildland Fire, 21, 114-126, 2012. 
Hua, Q. and Barbetti, M.: Review of tropospheric bomb ${ }^{14} \mathrm{C}$ data for carbon cycle modeling and age calibration purposes, Radiocarbon, 46, 1273-1298, 2004.

Hughen, K. A., Baillie, M. G., Bard, E., Beck, J. W., Bertrand, C. J., Blackwell, P. G., Buck, C. E., Burr, G. S., Cutler, K. B., and Damon, P. E.: Marine04 marine radiocarbon age calibration, 026 cal kyr BP, Radiocarbon, 46, 1059-1086, 2004.

Iglesias, V., Whitlock, C., Markgraf, V., and Bianchi, M. M.: Postglacial history of the Patagonian forest/steppe ecotone (41$43^{\circ} \mathrm{S}$ ), Quaternary Sci. Rev., 94, 120-135, 2014.

Ineson, S., Scaife, A. A., Knight, J. R., Manners, J. C., Dunstone, N. J., Gray, L. J., and Haigh, J. D.: Solar forcing of winter climate variability in the Northern Hemisphere, Nat. Geosci., 4, 753-757, 2011.

Ito, T., Woloszyn, M., and Mazloff, M.: Anthropogenic carbon dioxide transport in the Southern Ocean driven by Ekman flow, Nature, 463, 80-83, 2010.

Jessen, C. A., Solignac, S., Nørgaard-Pedersen, N., Mikkelsen, N., Kuijpers, A., and Seidenkrantz, M.-S.: Exotic pollen as an indicator of variable atmospheric circulation over the Labrador Sea region during the mid to late Holocene, J. Quaternary Sci., 26, 286-296, 2011.

Karpechko, A. Y., Gillett, N. P., Marshall, G. J., and Screen, J. A.: Climate impacts of the Southern Annular Mode simulated by the CMIP3 models, J. Climate, 22, 3751-3768, 2009.

Kilian, R. and Lamy, F.: A review of Glacial and Holocene paleoclimate records from southernmost Patagonia (49-55 $\mathrm{S})$, Quaternary Sci. Rev., 53, 1-23, 2012.

Kuroda, Y. and Yamazaki, K.: Influence of the solar cycle and QBO modulation on the Southern Annular Mode, Geophys. Res. Lett., 37, L12703, doi:10.1029/2010GL043252, 2010.

Lamy, F., Kilian, R., Arz, H. W., Francois, J.-P., Kaiser, J., Prange, M., and Steinke, T.: Holocene changes in the position and intensity of the southern westerly wind belt, Nat. Geosci., 3, 695-699, 2010.

Le Quére, C., Raupach, M. R., Canadell, J. G., and Marland, G. E. A.: Trends in the sources and sinks of carbon dioxide, Nat. Geosci., 2, 831-836, doi:10.1038/ngeo1689, 2009.

Lenton, A., Tilbrook, B., Law, R. M., Bakker, D., Doney, S. C., Gruber, N., Ishii, M., Hoppema, M., Lovenduski, N. S., Matear, R. J., McNeil, B. I., Metzl, N., Mikaloff Fletcher, S. E., Monteiro, P. M. S., Rödenbeck, C., Sweeney, C., and Takahashi, T.: Seaair $\mathrm{CO}_{2}$ fluxes in the Southern Ocean for the period 1990-2009, Biogeosciences, 10, 4037-4054, doi:10.5194/bg-10-4037-2013, 2013.

Leventer, A., Domack, E. W., Ishman, S. E., Brachfeld, S., McClennen, C. E., and Manley, P.: Productivity cycles of 200-300 years in the Antarctic Peninsula region: Understanding linkages among the sun, atmosphere, oceans, sea ice, and biota, Geol. Soc. Am. Bull., 108, 1626-1644, 1996.

Lisé-Pronovost, A., St-Onge, G., Gogorza, C., Haberzettl, T., Jouve, G., Francus, P., Ohlendorf, C., Gebhardt, C., Zolitschka, B., and Team, P. S.: Rock-magnetic proxies of wind intensity and dust since 51,200 cal BP from lacustrine sediments of Laguna Potrok Aike, southeastern Patagonia, Earth Planet. Sc. Lett., 411, 72-86, 2015.

Liu, J. and Curry, J. A.: Accelerated warming of the Southern Ocean and its impacts on the hydrological cycle and sea ice, P. Natl. Acad. Sci., 107, 14987-14992, 2010.
Macphail, M. and Cantrill, D. J.: Age and implications of the Forest Bed, Falkland Islands, southwest Atlantic Ocean: Evidence from fossil pollen and spores, Palaeogeogr. Palaeocl., 240, 602-629, 2006.

Marshall, G.: Trends in the Southern Annular Mode from observations and reanalyses, J. Climate, 16, 4134-4143, 2003.

Marshall, J. and Speer, K.: Closure of the meridional overturning circulation through Southern Ocean upwelling, Nat. Geosci., 5, 171-180, 2012.

Martin, T., Park, W., and Latif, M.: Multi-centennial variability controlled by Southern Ocean convection in the Kiel Climate Model, Clim. Dynam., 40, 2005-2022, 2013.

McGlone, M., Wilmshurst, J. M., and Wiser, S. K.: Lateglacial and Holocene vegetation and climatic change on Auckland Island, Subantarctic New Zealand, The Holocene, 10, 719-728, 2000.

McGlone, M. S., Turney, C. S. M., Wilmshurst, J. M., and Pahnke, K.: Divergent trends in land and ocean temperature in the Southern Ocean over the past 18,000 years, Nat. Geosci., 3, 622-626, 2010.

Messié, M. and Chavez, F.: Global modes of sea surface temperature variability in relation to regional climate indices, J. Climate, 24, 4314-4331, 2011.

Moreno, P., François, J., Villa-Martínez, R., and Moy, C.: Millennial-scale variability in Southern Hemisphere westerly wind activity over the last 5000 years in SW Patagonia, Quaternary Sci. Rev., 28, 25-38, 2009.

Moreno, P. I., Vilanova, I., Villa-Martínez, R., Garreaud, R. D., Rojas, M., and De Pol-Holz, R.: Southern Annular Mode-like changes in southwestern Patagonia at centennial timescales over the last three millennia, Nat. Commun., 5, 4375, doi:10.1038/ncomms5375, 2014.

Oeschger, H., Siegenthaler, U., Schotterrer, U., and Gugelmann, A.: A box diffusion model to study the carbon dioxide exchange in nature, Tellus, 27, 168-192, 1975.

Otley, H., Munro, G., Clausen, A., and Ingham, B.: Falkland Islands State of the Environment Report. Falkland Islands Government and Falklands Conservation, Stanley, Falkland Islands, 2008.

Paillard, D., Labeyrie, L., and Yiou , P.: Macintosh program performs time-series analysis, Eos, 77, p. 379, 1996.

Poore, R. Z., Quinn, T. M., and Verardo, S.: Century-scale movement of the Atlantic Intertropical Convergence Zone linked to solar variability, Geophys. Res. Lett., 31, L12214, doi:10.1029/2004GL019940, 2004.

Reimer, P. J., Bard, E., Bayliss, A., Beck, J. W., Blackwell, P. G., Bronk Ramsey, C., Grootes, P. M., Guilderson, T. P., Haflidason, H., Hajdas, I., Hatté, C., Heaton, T. J., Hoffmann, D. L., Hogg, A. G., Hughen, K. A., Kaiser, K. F., Kromer, B., Manning, S. W., Niu, M., Reimer, R. W., Richards, D. A., Scott, E. M., Southon, J. R., Staff, R. A., Turney, C. S. M., and van der Plicht, J.: IntCal13 and Marine13 radiocarbon age calibration curves $0-50,000$ years cal BP, Radiocarbon, 55, 1869-1887, 2013.

Roig, F. A., Le-Quesne, C., Boninsegna, J. A., Briffa, K. R., Lara, A., Grudd, H., Jones, P. D., and Villagrán, C.: Climate variability 50,000 years ago in mid-latitude Chile as reconstructed from tree rings, Nature, 410, 567-570, 2001.

Rose, N. L., Jones, V. J., Noon, P. E., Hodgson, D. A., Flower, R. J., and Appleby, P. G.: Long-range transport of pollutants to the Falkland Islands and Antarctica: Evidence from lake sediment 
fly ash particle records, Environ. Sci. Technol., 46, 9881-9889, 2012.

Ruf, T.: The Lomb-Scargle periodogram in biological rhythm research: Analysis of incomplete and unequally spaced time-series, Biol. Rhythm Res., 30, 178-201, 1999.

Scott, L. and van Zinderen Barker, E. M.: Exotic pollen and longdistance wind dispersal at a Sub-Antarctic island, Grana, 24, 4554, 1985.

Shindell, D., Rind, D., Balachandran, N., Lean, J., and Lonergan, P.: Solar cycle variability, ozone and climate, Science, 284, 305308, 1999.

Steinhilber, F., Beer, J., and Fröhlich, C.: Total solar irradiance during the Holocene, Geophys. Res. Lett., 36, L19704, doi:19710.11029/12009g1040142, 2009.

Steinhilber, F., Abreu, J. A., Beer, J., Brunner, I., Christl, M., Fischer, H., Heikkilä, U., Kubik, P. W., Mann, M., McCracken, K. G., Miller, H., Miyahara, H., Oerter, H., and Wilhelms, F.: 9,400 years of cosmic radiation and solar activity from ice cores and tree rings, P. Natl. Acad. Sci. USA, 109, 5967-5971, 2012.

Strother, S. L., Salzmann, U., Roberts, S. J., Hodgson, D. A., Woodward, J., Van Nieuwenhuyze, W., Verleyen, E., Vyverman, W., and Moreton, S. G.: Changes in Holocene climate and the intensity of Southern Hemisphere Westerly Winds based on a highresolution palynological record from sub-Antarctic South Georgia, The Holocene, 25, 263-279, 2015.

Stuiver, M. and Braziunas, T. F.: Modeling atmospheric ${ }^{14} \mathrm{C}$ influences and ${ }^{14} \mathrm{C}$ ages of marine samples to $10,000 \mathrm{BC}$, Radiocarbon, 35, 137-189, 1993a.

Stuiver, M. and Braziunas, T. F.: Sun, ocean, climate and atmospheric ${ }^{14} \mathrm{CO}_{2}$ : an evaluation of causal and spectral relationships, The Holocene, 3, 289-305, 1993b.

Thomson, D. J.: Spectrum estimation and harmonic analysis, P. IEEE, 70, 1055-1096, 1982.

Thompson, D. W. J., Solomon, S., Kushner, P. J., England, M. H., Grise, K. M., and Karoly, D. J.: Signatures of the Antarctic ozone hole in Southern Hemisphere surface climate change, Nat. Geosci., 4, 741-749, 2011.

Torrence, C. and Webster, P. J.: Interdecadal changes in the ENSOMonsoon system, J. Climate, 12, 2679-2690, 1999.

Turney, C. S. M., Baillie, M., Clemens, S., Brown, D., Palmer, J., Pilcher, J., Reimer, P., and Leuschner, H. H.: Testing solar forcing of pervasive Holocene climate cycles, J. Quaternary Sci., 20, 511-518, 2005.
Turney, C. S. M., McGlone, M., Palmer, J., Fogwill, C., Hogg, A., Thomas, Z. A., Lipson, M., Wilmshurst, J. M., Fenwick, P., Jones, R. T., Hines, B., and Clark, G. F.: Intensification of Southern Hemisphere westerly winds 2000-1000 years ago: evidence from the subantarctic Campbell and Auckland Islands (52-50 S), J. Quaternary Sci., 31, 12-19, doi:10.1002/jqs.2828, 2016.

Upton, J. and Shaw, C. J.: An overview of the oceanography and meteorology of the Falkland Islands, Aquat. Conserv., 12, 15$25,2002$.

van Oldenborgh, G. J. and Burgers, G.: Searching for decadal variations in ENSO precipitation teleconnections, Geophys. Res. Lett., 32, L15701, doi:15710.11029/12005GL023110, 2005.

Veblen, T. T., Hill, R. S., and Read, J.: The ecology and biogeography of Nothofagus forests, Yale University Press, New Haven, 411 pp., 1996.

Villalba, R., Lara, A., Masiokas, M. H., Urrutia, R., Luckman, B. H., Marshall, G. J., Mundo, I. A., Christie, D. A., Cook, E. R., Neukom, R., Allen, K., Fenwick, P., Boninsegna, J. A., Srur, A. M., Morales, M. S., Araneo, D., Palmer, J. G., Cuq, E., Aravena, J. C., Holz, A., and LeQuesne, C.: Unusual Southern Hemisphere tree growth patterns induced by changes in the Southern Annular Mode, Nat. Geosci., 5, 793-798, 2012.

Visbeck, M.: A station-based Southern Annular Mode Index from 1884 to 2005, J. Climate, 22, 940-950, 2009.

Wang, P.-L., Pu, F.-T., and Zheng, Z.-H.: Pollen morphology of the genus Nothofagus and its taxonomic significance, Acta Phytotax. Sin., 38, 452-461, 2000.

Whitlock, C. and Larsen, C.: Charcoal as a fire proxy. In: Tracking Environmental Change using Lake Sediments, Springer Netherlands, Dordrecht, The Netherlands, 2001.

Wilson, P., Clark, R., Birnie, J., and Moore, D. M.: Late Pleistocene and Holocene landscape evolution and environmental change in the Lake Sulivan area, Falkland Islands, South Atlantic, Quaternary Sci. Rev., 21, 1821-1840, 2002.

Wilson, V. R. and Owens, J. N.: The reproductive biology of Totara (Podocarpus totara) (Podocarpaceae), Ann. Bot., 83, 401-411, 1999.

Yin, J. H.: A consistent poleward shift of the storm tracks in simulations of 21 st century climate, Geophys. Res. Lett., 32, L18701, doi:18710.11029/12005GL023684, 2005. 